\title{
Editorial 1/2010
}

\section{Leyre Maiso Fontecha}

Published online: 16 April 2010

(C) ERA 2010

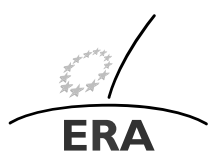

EUROPÄISCHE RECHTSAKADEMIE ACADEMY OF EUROPEAN LAW ACADEMIE DE DROIT EUROPEEN ACCADEMIA DI DIRITTO EUROPEO TRIER - TREVES - TREVIRI

Abstract In this first issue of ERA Forum of 2010 a number of articles are presented dealing primarily with different and current topics of European private law.

\section{European civil procedure}

The Brussels I Regulation ${ }^{1}$ lays down rules governing the jurisdiction of courts and the recognition and enforcement of judgments in civil and commercial matters in the Member States of the European Union. It supersedes the Brussels Convention of 1968, which was applicable between the Member States before the Regulation entered into force in 2002. The Brussels I Regulation is currently under review by the European Commission. ${ }^{2}$ Among the issues raised are those concerning the treatment of choice of court agreements. By an exclusive choice of court agreement, the parties designate which court will decide disputes in connection with a particular legal rela-

\footnotetext{
${ }^{1}$ Council Regulation (EC) No 44/2001 of 22 December 2000 on jurisdiction and the recognition and enforcement of judgments in civil and commercial matters. OJ L 012, 16.01.2001.

${ }^{2}$ For more information on the ongoing review, see: Report from the Commission to the European Parliament, the Council and the European Economic and Social Committee on the application of Council Regulation (EC) No 44/2001 on jurisdiction and the recognition and enforcement of judgments in civil and commercial matters, COM (2009) 174 final; and Green Paper on the review of Council Regulation (EC) No 44/2001 on jurisdiction and the recognition and enforcement of judgments in civil and commercial matters of 21 April 2009, COM (2009) 175 final.
}

Deputy Head of Section-European Private Law.

L. Maiso Fontecha $(\bowtie)$

Academy of European Law, Metzer Allee 4,

54295 Trier, Germany

e-mail:1maiso@era.int 
tionship, to the exclusion of the jurisdiction of any other courts. Two of the articles illustrate current issues dealing with choice of court agreements.

The first one concerns the admissibility of damages in case of breach of a choice of court agreement. Gilles Cuniberti and Marta Requejo explain how, in the last decade, English and Spanish Courts have awarded damages in case of a breach of this clause. Until recently, the most efficient remedy was to seek an antisuit injunction in England, an order restraining a party from commencing or continuing proceedings in a foreign jurisdiction. This was however considered incompatible with European Union law in several cases decided by the European Court of Justice. ${ }^{3}$ The European Commission has nevertheless suggested in the Green Paper on the review of the Brussels I Regulation that the efficiency of jurisdiction agreements could be strengthened by granting damages for breach of such agreements.

The second article by Marta Pertegás presents the Hague Convention of 30 June 2005 on Choice of Court Agreement. This instrument, not yet in force, establishes uniform rules on jurisdiction and on recognition and enforcement of foreign judgments in civil or commercial matters. The Convention would prevail over the Brussels I Regulation in cases where one party resides in an EU Member State and the other in a non-EU Member State that is a party to the Convention. The author argues that, in order to ensure that co-ordination is achieved between the Convention and the future revised European regulation, the Convention should serve as a source of inspiration as to possible amendments to the Brussels I Regulation with regard to choice of court clauses.

\section{Private international law}

The Rome Convention of 1980 on the law applicable to contractual obligations entered into force on 1 April 1991 to complement the Brussels Convention of 1968 by harmonising the rules of conflict of laws applicable to contracts. Like the Brussels Convention, the Rome Convention has been recently converted into a Community instrument. The Rome I Regulation, ${ }^{4}$ applicable since 17 December 2009, also modernises some of its rules. The article of Monika Pauknerová looks into the changes brought by the Rome I Regulation regarding mandatory rules and public policy. Mandatory rules are those which cannot be derogated by contract and which are declared binding by a legal system. In international cases, these can be "overriding" mandatory rules, which cannot be contracted out by the parties by choosing the law of another country. These must be differentiated from the public policy exception, which occurs when the application of a rule of the law of any country specified by the conflict rules may be refused if such application is manifestly incompatible with the fundamental principles of national public policy of the forum State. The author assesses positively the regulation of mandatory rules in the Rome I Regulation, which

\footnotetext{
${ }^{3}$ Case C-116/02 Gasser [2003] ECR I-14693; Case C-159/02 Turner [2004] ECR I-3565; Case C-185/07 West Tankers, not yet reported.

${ }^{4}$ Regulation (EC) No 593/2008 of the European Parliament and of the Council of 17 June 2008 on the law applicable to contractual obligations (Rome I). OJ L 177/6, 4.7.2008.
} 
clearly distinguishes between mandatory rules and overriding mandatory rules, but notes that many issues still remain unsolved, such as the scope and conditions of application of the overriding mandatory provisions.

The conflict of law rules for non-contractual obligations have also been harmonised at EU level to complement both the Brussels I Regulation (which relates to both contractual and non-contractual obligations) and the Rome I Convention (nowadays a Regulation). The Rome II Regulation ${ }^{5}$ creates a harmonised set of rules within the European Union to govern choice of law in civil and commercial matters concerning non-contractual obligations. One of the fields of tort law it regulates is product liability. The article of Guillermo Palao Moreno, which is of high practical importance, analyses the conflict of law rule for product liability cases contained in Article 5 of the Rome II Regulation. In his thorough analysis of Article 5 of the Rome II Regulation, read in conjunction with the other provisions of the Regulation, the author points out that its application could however lead to an undesirable result. Although the inclusion of a specific provision for product liability primarily aims at avoiding the application of the general conflict of law rule of the law of the country in which the damage occurs, Article 5 maintains those solutions present in paragraphs 2 and 3 of Article 4. Furthermore, the author calls for clarification as to the coordination of the Rome II Regulation with the Hague Convention of 2 October 1973 on the Law Applicable to Products Liability.

\section{European consumer law}

This analysis is followed by an article on consumer law. Christophe Verdure presents a chronicle of recent cases from the European Court of Justice, delivered from $1 \mathrm{Au}-$ gust 2008 to 31 July 2009, a period of time where a considerable number of cases was decided. The cases presented deal with a range of different topics of consumer law such as commercial practices, including unfair commercial practices, distance contracts and misleading advertising, matters of consumer contracts, including unfair terms, consumer credit and electronic commerce, product liability, air passenger rights as well as issues of jurisdiction over consumer contracts.

\section{International transport law}

ERA organised on 30 November-1 December 2009 its first annual conference on European transport law, aiming at providing practitioners in the field of transport law with an overview of the latest developments in European legislation and jurisprudence. A paper from this conference is included in this issue of ERA Forum. Simone Lamont-Black first introduces the different international Conventions applicable to the transportation of goods for each mode of transport: sea, inland waterways, rail,

\footnotetext{
${ }^{5}$ Regulation (EC) No 864/2007 of the European Parliament and of the Council of 11 July 2007 on the law applicable to non-contractual obligations (Rome II). OJ L 199/40, 31.7.2007.
} 
road or air. She then focuses on identifying the competent jurisdiction and the applicable law to international carriage of goods. Rules on the jurisdiction contained in specialised Conventions would prevail over the Brussels I Regulation which would nevertheless be applicable for all matters not regulated by these specialised Conventions. As to the law applicable, the Rome I and Rome II Regulations would apply. If the law applicable corresponds to that of a country that has ratified an international convention, these rules can be applied as incorporated into the legal system within its scope and limits of application.

\section{European gender equality law}

A different area of European private law is dealt with by Susanne Burri in her article on the reconciliation of work and private life in EU law. Reconciliation measures are those aiming at enabling people to combine their family responsibilities and occupational ambitions. They can be related to child-care, care of the elderly, parental leave, maternity leave or flexible working arrangements. Developments in this area are essential not only for gender equality but also in the context of an ageing population. The Commission presented a reconciliation package in October 2008 including a communication ${ }^{6}$ and two legislative proposals. The first one ${ }^{7}$ aims to amend Directive 86/613/ECC on the application of the principle of equal treatment of the self-employed and their assisting spouses. This proposal extends the parental leave rights of employees to self-employed women, as well as providing rights for "assisting spouses", who often work in the self-employed sector without enjoying the corresponding rights. The Council reached a political agreement on 30 November 2009 and extended the scope of the directive to life partners recognised by national law. The second proposal ${ }^{8}$ aims to strengthen women's legal entitlement to familyrelated leave, namely maternity leave, amending Directive 92/85/ECC, by extending the duration of maternity leave from 14 to 18 weeks. Negotiations are undergoing. Another recent development on this matter is the revised framework agreement on parental leave concluded by the social partners on 18 June 2009. The new agreement increases parental leave from three to four months for each parent, applies to all workers regardless of their type of contract, gives parents returning to work after parental leave the opportunity to request a change to their working conditions, and increases protection against any unfavourable treatment as a result of the exercise

\footnotetext{
${ }^{6}$ Communication from the Commission to the European Parliament, the Council, the Economic and Social Committee and the Committee of the Regions: A better work-life balance: stronger support for reconciling professional, private and family life. COM(2008) 635 final.

${ }^{7}$ Proposal for a Directive of the European Parliament and of the Council on the application of the principle of equal treatment between men and women engaged in an activity in a self-employed capacity and repealing Directive 86/613/EEC. COM(2008) 636 final.

${ }^{8}$ Proposal for a Directive of the European Parliament and of the Council amending Council Directive 92/85/EEC on the introduction of measures to encourage improvements in the safety and health at work of pregnant workers and workers who have recently given birth or are breastfeeding. COM(2008) 637 final.
} 
of the right to parental leave. The Council reached a political agreement on 30 November 2009 on the Commission proposal for a Directive implementing the revised framework agreement. ${ }^{9}$

\section{European water management law}

Finally, this issue also includes an article on European water management law, following the two articles on this topic already published in the previous issue of ERA Forum. ${ }^{10}$ Marleen van Rijswick, Herman Kasper Gilissen and Jasper van Kempen present the river basin approach for European water management following the introduction of the Water Framework Directive ${ }^{11}$ in 2001. This approach divides water flows into geographically allocated river basins, for which Member States within a river basin share responsibilities. Such cooperation is problematic in practice. The authors argue that cooperation in transboundary water management should take place on both the international and the regional level.

\footnotetext{
${ }^{9}$ Proposal for a Council Directive implementing the revised framework agreement on parental leave concluded by BUSINESSEUROPE, UEAPME, CEEP and ETUC and repealing Directive 96/34/EC. $\operatorname{COM}(2009) 410$ final.

${ }^{10}$ Howarth W: Costs recovery for water services and polluter pays principle, ERA Forum 10(4), 565 (2009). doi:10.1007/s12027-009-0134-3; Bin F.: Analyse comparée des incitations fiscales en Europe pour la gestion de l'eau, ERA Forum 10(4), 589 (2009). doi:10.1007/s12027-009-0136-1.

${ }^{11}$ Directive 2000/60/EC of the European Parliament and of the Council of 23 October 2000 establishing a framework for Community action in the field of water policy. OJ L 327, 22.12.2000.
} 